\title{
Effect of Steel Fibers and GFRP Sheet on the Behavior of Lightweight Concrete Specimens Using Waste Lightweight Sand Bricks
}

\author{
Sameh Yehia \\ Assistant Professor \\ Higher Institute of Engineering, El-Shorouk Academy \\ Cairo, Egypt
}

\begin{abstract}
High performance traditional and optimized lightweight fibrous concrete was investigated by using steel fibers and glass fiber reinforced polymer (GFRP) sheet, double action of Fibers. Basically, fibers could controlled the cracking of concrete, crack propagation and crack width. However, using fibers capable of enhancing failure mode of concrete to semiductile or ductile mode. Experimental work was consist of two phases, the first phase was focused on cast traditional fibrous concrete specimens in addition to control specimens to compare obtained results. These specimens were cubes, cylinders and prisms, which were tested after seven, fourteen and twenty eight days. Three percentages of round crimped (corrugated) steel fibers $(0.5 \%, 1 \%$ and $1.5 \%)$ were used to get the optimum percentage. The second phase was concerned with cast lightweight concrete specimens by using the obtained optimum percentage of steel fibers. Specimens were cast by using waste lightweight sand bricks as an coarse aggregate (replacement percentage $50 \%$ of actual weight). The effect of strengthening with external GFRP sheet was studied for traditional and lightweight concrete specimens. The results confirmed that, steel fibers and GFRP sheet (external strengthening) increased the studied mechanical properties with competitive values in comparison to traditional concrete.
\end{abstract}

Keywords-Green Concrete, Lightweight Concrete, Fibrous Concrete, Recycling, External Strengthening, GFRP.

\section{INTRODUCTION}

Fiber reinforced concrete (FRC) may be defined as a composite materials producing by using Portland Cement, aggregate (coarse and fine), and incorporating with fibers. Recently, adding fiber could enhance the brittle behavior of concrete material. Basically, the role of randomly distribute of fibers is to overcome the crack propagation to enhance some post-cracking (ductility) and optimizing low tensile strength and strain capacity. Mechanical properties of traditional and lightweight fibrous concrete were investigated, in addition to comparing results with strengthened (GFRP) sheet, traditional and lightweight concrete specimens. Fibrous specimens which were strengthened called double action of fibers concrete. Waste lightweight broken sand bricks were used as a coarse aggregate with $50 \%$ replacement of total weight of aggregate to producing lightweight concrete specimens.

Hassan et. al, (2012)[1] studied the influence of using fibers on the properties of different types of lightweight aggregate concrete (LWAC). These properties included the fresh and hardened properties. Basically, the inclusion of fibers in LWAC (single or hybrid) improved the mechanical properties, and significantly increase its toughness, ductility performance and energy absorption, while decreasing its workability, particularly when steel fibers is used in the concrete mixture. In the case of splitting tensile and flexural strengths, the effectiveness of fiber in LWAC is more pronounced than normal weight concrete (NWC). R.Yua, et. al, (2016)[2] developed the usage of Ultra-Lightweight Fiber Reinforced Concrete (ULFRC) applying expanded waste glass in form of lightweight aggregates. The mechanical properties and thermal conductivity in addition to density of the developed ULFRC are measured. The ULFRC with a dry density of $750 \mathrm{~kg} / \mathrm{m}^{3}$ is produced. It is found that hybridization and an optimized amount of polypropylene fibers are beneficial for improving the mechanical properties of ULFRC. However, according to different types of lightweight concrete with the same density, the ULFRC improved mechanical properties and lower thermal conductivity.

N. Sivalinga Rao et. al, (2013)[3] investigated the utilization of lightweight materials in structural applications. The target means strength of M20 concrete is achieved with $20 \%$ replacement of natural coarse aggregate by pumice aggregate and with $1.5 \%$ of steel fibers. Also with $40 \%$ pumice and with $0.5 \%$ of steel fibers average target mean strength of M20 concrete is achieved. The compressive strength of pumice concrete increased by increasing fiber content and reached to optimum value at $1.5 \%$ of fiber content and afterwards it gets decreased for various contents of pumice. Aghaee, K et. al, (2014)[4] studied structural lightweight concrete blended with waste steel wires taken from steel reinforcement and formworks which were previously used in buildings and infrastructures projects. The scope was to replace the industrial steel fibers of controlled quality with recycled ones. Compressive, tensile, flexural and impact tests were performed observing the mechanical properties of a twenty eight days reinforced concrete (RC) specimen to compare with the same apparatus of $\mathrm{RC}$ with mixed steel wires, mixed steel fibers as well as plain concrete. The percentage of fibers on all fiber reinforced concrete (FRC) specimens was $0.25 \%, 0.5 \%$ and $0.75 \%$ in volume fraction of the concrete. It was concluded that, the waste wires could be used as a suitable and promising alternative to steel fibers in structural lightweight concrete. 


\section{EXPERIMENTAL WORK PROGRAM}

Natural crushed stone with a max. nominal size of $10 \mathrm{~mm}$ was used and complied with ES:1109/2002[5]. Natural clean siliceous sand was tested according to ES:1109/2002[5], Table (1) and (2) show the properties of the used aggregate. Portland Cement type CEM I-42.5N was used and tested according to ES: 4756-1/2009[6]. Table (3) shows the chemical analysis and physical properties of the used cement according to ES:4756-1/2009[6]. Clean tap drinking water was used. The quantities of concrete ingredients were $1200 \mathrm{~kg} / \mathrm{m}^{3}$ (coarse aggregate), $\quad 600 \mathrm{~kg} / \mathrm{m}^{3}$ (fine aggregate), $\quad 350 \mathrm{~kg} / \mathrm{m}^{3}$ (cement content) and $190 \mathrm{~kg} / \mathrm{m}^{3}$ (water content). The w/c ratio was 0.54 , this value was fixed in all concrete mixtures and was taken higher to obtain suitable consistency to cast specimens. The steel fibers quantities were $39 \mathrm{~kg} / \mathrm{m}^{3}, 78 \mathrm{~kg} / \mathrm{m}^{3}, 117 \mathrm{~kg} / \mathrm{m}^{3}$ for $0.5 \%, 1 \%$ and $1.5 \%$, respectively. The design of concrete mixtures were carried out in complying with BS:5328[7].

Table (1): Physical Properties of the Used Crushed Stone

\begin{tabular}{|c|c|c|}
\hline Test & Results & Acceptable Limit \\
\hline Specific Gravity & 2.65 & - \\
\hline Unit Weight $\left(\mathrm{t} / \mathrm{m}^{3}\right)$ & 1.65 & - \\
\hline Materials Finer than No 200 Sieve & 1.85 & Less than 3\% \\
\hline Absorption \% & 1.95 & Less than $2.5 \%$ \\
\hline Abrasion (Los Anglos) & 16.85 & Less than $30 \%$ \\
\hline Crushing Value & 18.55 & Less than $30 \%$ \\
\hline Impact & 12.85 & Less than $45 \%$ \\
\hline
\end{tabular}

Table (2): Physical Properties of the Used Sand

\begin{tabular}{|c|c|c|}
\hline Test & Results & Acceptable Limit \\
\hline Specific Gravity & 2.75 & - \\
\hline Unit Weight $\left(\mathrm{t} / \mathrm{m}^{3}\right)$ & 1.75 & - \\
\hline Materials Finer than No 200 Sieve & 1.50 & Less than $3 \%$ \\
\hline Absorption $\%$ & 1.05 & Less than $2.5 \%$ \\
\hline
\end{tabular}

Table (3): Properties of Used Cement (CEM I 42.5N)

\begin{tabular}{|c|c|c|c|}
\hline \multicolumn{2}{|l|}{ Properties } & $\begin{array}{l}\text { Measured } \\
\text { Values }\end{array}$ & $\begin{array}{l}\text { Limits of the } \\
\text { E.S.S* }\end{array}$ \\
\hline \multicolumn{2}{|l|}{ Fineness $\left(\mathrm{cm}^{2} / \mathrm{gm}\right)$} & 3280 & - \\
\hline \multicolumn{2}{|l|}{ Specific Gravity } & 3.15 & - \\
\hline \multicolumn{2}{|l|}{ Expansion (mm) } & 1.30 & Not more than 10 \\
\hline \multicolumn{2}{|c|}{$\begin{array}{c}\text { Consistence of Standard Cement } \\
\text { Paste (Water Percentage) }\end{array}$} & $26 \%$ & - \\
\hline \multicolumn{2}{|c|}{ Initial Setting Time (min) } & 165 & $\begin{array}{l}\text { Not less than } 60 \\
\text { min }\end{array}$ \\
\hline \multicolumn{2}{|c|}{ Final Setting Time (min) } & 210 & - \\
\hline \multirow{3}{*}{$\begin{array}{c}\text { Compressive Strength } \\
\left(\mathrm{N} / \mathrm{mm}^{2}\right)\end{array}$} & $\begin{array}{c}2 \\
\text { days }\end{array}$ & 24.5 & Not less than 10 \\
\hline & $\begin{array}{c}7 \\
\text { days }\end{array}$ & 36.5 & - \\
\hline & $\begin{array}{c}28 \\
\text { days }\end{array}$ & 59.4 & $\begin{array}{l}\text { Not less than } 42.5 \\
\text { and not more than }\end{array}$ \\
\hline
\end{tabular}

\begin{tabular}{|c|c|c|c|}
\hline & & & 62.5 \\
\hline \multirow{7}{*}{ Chemical Compositions } & $\mathrm{SiO}_{2}$ & $21.16 \%$ & - \\
\hline & $\begin{array}{c}\mathrm{Al}_{2} \mathrm{O} \\
3\end{array}$ & $4.98 \%$ & - \\
\hline & $\begin{array}{c}\mathrm{Fe}_{2} \mathrm{O} \\
3\end{array}$ & $3.78 \%$ & - \\
\hline & $\mathrm{CaO}$ & $64.39 \%$ & - \\
\hline & $\mathrm{MgO}$ & $1.36 \%$ & - \\
\hline & $\mathrm{SO}_{3}$ & $1.95 \%$ & - \\
\hline & $\begin{array}{l}\text { Loss } \\
\text { Igniti } \\
\text { on } \%\end{array}$ & $1.35 \%$ & - \\
\hline
\end{tabular}

*Egyptian Standard Specifications No:4756-1/2009 [6].

Phase one, concrete mixtures were mixed with three different steel fibers percentages $(0.5 \%, 1 \%$ and $1.5 \%)$ to cast fibrous concrete specimens, in addition to mixture without steel fibers to produce control specimens. Table (4) shows the properties of the used steel fibers. All specimens were cured for seven days after cast and were tested after seven, fourteen and twenty eight days. Cubes were tested for compressive strength, cylinders for indirect tensile strength and prisms for flexural strength according to BS:12390[8]. Table shows the test results for specimens.

Phase two, waste lightweight sand bricks were used as a coarse aggregate for lightweight concrete by $50 \%$ replacement of total coarse aggregate weight in traditional concrete, the others quantities of concrete ingredients were fixed as phase one. The composition percentage of this aggregate was $85 \%$ siliceous sand, $9 \%$ lime, 5\% water and aluminum powder $1 \%$ according to chemical analysis by $\mathrm{x}$ ray. Figure (1) shows the used waste lightweight sand bricks (aggregate). Waste lightweight sand bricks were crushed with variable sizes to reach max. nominal size of $10 \mathrm{~mm}$ (simulate the aggregate of traditional concrete) and were tested according to ASTM C330[9], Table (5) shows test results. The optimized aggregate was painted with unsaturated polyester (to isolate lime in aggregate) which was mixed with $6 \mathrm{ml}$ of peroxide as a chemical catalyze per one kilo, called by resin (as stated in data sheet of supplier) and finally covered with cement mortar (to increase bond) which was mixed with 3:1 (sand to cement) and the water content $40 \%$ of cement content, ES:4756-1/2009[6]). This lead to decrease aggregate absorption by $98.5 \%$ because it's cover the surface of the used aggregate and overcame on undesirable behavior of absorption. However, this also, preserve mixing water which improved the workability while using steel fibers and the lime in the light weight sand brick aggregate is completely isolated from direct contact with mortar and water, leading to a reduction and even a long-term effect on the concrete durability. Table (6) shows the physical properties of used unsaturated polyester.

In this phase, all concrete mixtures except control mixture were mixed with $1 \%$ of steel fibers (the optimum obtained value and will be state in details at section 3.1. Results, Analysis and Discussions). Cubes, cylinders and prisms were strengthened with one layer of GFRP sheet after fourteen days from casting (to ensure specimens drying) and were tested after twenty eight days, Table (7) shows the 
physical properties of the used GFRP sheet. The strengthening process were included cleaning and roughening of specimens surface to increase the bond between GFRP sheet and concrete surface. GFRP sheet was cut with suitable fitted dimensions to full wrapping of different specimens. It's worth to be mention that, the overlap was $10 \mathrm{~cm}$ to verify overlap requirements Ghaniem, et al., (2009)[10]. Specimens were glued with unsaturated polyester which was mixed with $6 \mathrm{ml}$ of peroxide as a chemical catalyze per one kilo (as stated in data sheet of supplier). Figure (2) shows the test setup for strengthened specimens.

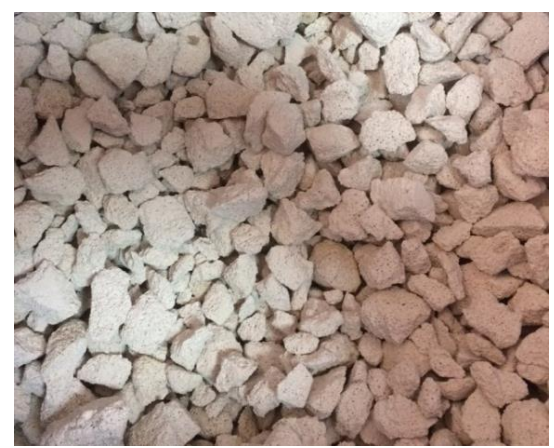

Figure (1): Waste Lightweight Sand Brick

Table (4): Properties of the Used Steel Fibers

\begin{tabular}{|c|c|c|}
\hline \multicolumn{2}{|c|}{ Property } & Obtained Value* \\
\hline \multicolumn{2}{|c|}{ Shape } & $\begin{array}{c}\text { Round Crimped } \\
\text { (Corrugated) }\end{array}$ \\
\hline \multirow{2}{*}{$\begin{array}{c}\text { Chemical Composition } \\
\text { Low Carbon drawn wire } \\
\text { Conforming to AISI } \\
1010[11]\end{array}$} & $\mathrm{C}$ & $0.08-0.10 \%$ \\
\cline { 2 - 3 } & $\mathrm{Si}$ & $0.05-0.1 . \%$ \\
\cline { 2 - 3 } & $\mathrm{Mn}$ & $0.6-0.80 \%$ \\
\cline { 2 - 3 } Length (mm) & $\mathrm{P}$ & $\max 0.015 \%$ \\
\hline Thickness (mm) & $\max 0.030 \%$ \\
\hline Aspect Ratio & 25 \\
\hline Unit Weight $\left(\mathrm{t} / \mathrm{m}^{3}\right)$ & 1 \\
\hline Young's Modulus $\left(\mathrm{N} / \mathrm{mm}^{2}\right)$ & 25 \\
\hline Tensile Strength $\left(\mathrm{N} / \mathrm{mm}^{2}\right)$ & 7.80 \\
\hline
\end{tabular}

*Obtained data from supplier.

Table (5): Physical Properties of the Used Lightweight Aggregate

\begin{tabular}{|c|c|c|}
\hline Test & Results & Specification Limit* \\
\hline Specific Gravity & 13.30 & - \\
\hline $\begin{array}{c}\text { Unit Weight } \\
\left(\mathbf{t} / \mathbf{m}^{\mathbf{3}}\right)\end{array}$ & 0.35 & Less than $\mathbf{0 . 8 8 t} / \mathbf{m}^{\mathbf{3}}$ \\
\hline $\begin{array}{c}\text { Absorption \% } \\
\text { (achieved after 30mins } \\
\text { then fixed for 24hrs) }\end{array}$ & $75 \%$ & - \\
\hline $\begin{array}{c}\text { Absorption \% } \\
\text { (covered aggregate) }\end{array}$ & $1.1 \%$ & - \\
\hline
\end{tabular}

*ASTM C330, ACI:213R-03 [9] [12].
Table (6): Physical Properties of The Used Unsaturated Polyester

\begin{tabular}{|c|c|}
\hline Properties & $\begin{array}{c}\text { Obtained* } \\
\text { Values }\end{array}$ \\
\hline Density $\left(\mathrm{g} / \mathrm{cm}^{3}\right)$ & 1.09 \\
\hline Modulus of Elasticity $\left(\mathrm{N} / \mathrm{mm}^{2}\right)$ & $3.3 \times 10^{3}$ \\
\hline Flexural Strength $\left(\mathrm{N} / \mathrm{mm}^{2}\right)$ & 45 \\
\hline Tensile Strength $\left(\mathrm{N} / \mathrm{mm}^{2}\right)$ & 40 \\
\hline Maximum Elongation $(\%)$ & 1 \\
\hline Viscosity at $25^{\circ} \mathrm{C} \mu(\mathrm{cP})$ & 250 \\
\hline
\end{tabular}

*Obtained data from supplier.

Table (7): Physical Properties of the Used GFRP Sheet

\begin{tabular}{|c|c|}
\hline Properties & Values \\
\hline Thickness & $1 \mathrm{~mm}^{*}$ \\
\hline Strength at Failure & $2650 \mathrm{~kg} / \mathrm{cm}^{2 * *}$ \\
\hline
\end{tabular}

*Obtained from data sheet of supplier.

**Tested at Lab under the effect of tension force according to ECP:2082005[13]

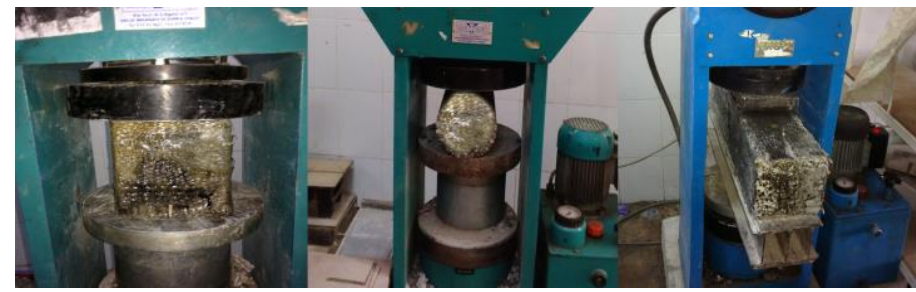

Figure (2): Test setup for Strengthened Specimens

\section{RESULTS, ANALYSIS AND DisCUSSIONS}

Testing machine of capacity 200ton was used Testing process was carried out according to BS:12390[8]. Cubes, cylinders and prisms were tested after seven, fourteen and twenty eight days for compressive strength, indirect tensile strength and flexural strength, respectively. The following Table (8) summarized the test results for all mixtures. Also, established that steel fibers improved the mechanical properties of both traditional and lightweight concrete at different ages. The enhancement in traditional concrete appeared more significantly than lightweight concrete. The explanation due be attribute to percentage of aggregate were used in traditional concrete. Using GFRP external sheet, also increased the enhancement value more over.

Table (8): Mechanical Properties of Tested Specimens

\begin{tabular}{|c|c|c|c|c|c|c|c|}
\hline 竞 & $\begin{array}{l}\text { Mechanical } \\
\text { Properties }\end{array}$ & 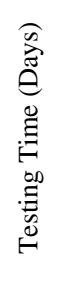 & 营 & 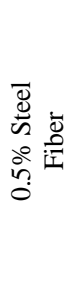 & $\begin{array}{l}\bar{\Xi} \\
\frac{d}{0} \\
\dot{0} \\
0 \\
0\end{array}$ & 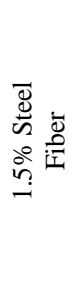 & 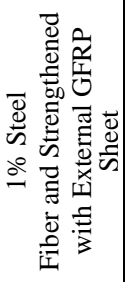 \\
\hline \multirow{6}{*}{ 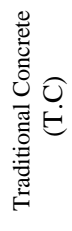 } & \multirow{3}{*}{$\begin{array}{c}\text { Compressive } \\
\text { Strength* } \\
\left(\mathrm{kg} / \mathrm{cm}^{2}\right) \\
\end{array}$} & 7 & 156 & 190 & 229 & 204 & - \\
\hline & & 14 & 190 & 243 & 287 & 265 & - \\
\hline & & 28 & 237 & 296 & 342 & 323 & 406 \\
\hline & \multirow{3}{*}{$\begin{array}{l}\text { Indirect } \\
\text { Tensile } \\
\text { Strength* } \\
\left(\mathrm{kg} / \mathrm{cm}^{2}\right)\end{array}$} & 7 & 13 & 16 & 24 & 17 & - \\
\hline & & 14 & 16 & 19 & 29 & 23 & - \\
\hline & & 28 & 19 & 24 & 36 & 29 & 67 \\
\hline
\end{tabular}




\begin{tabular}{|c|c|c|c|c|c|c|c|}
\hline & \multirow{3}{*}{$\begin{array}{l}\text { Flexural } \\
\text { Strength* } \\
\left(\mathrm{kg} / \mathrm{cm}^{2}\right)\end{array}$} & 7 & 22 & 27 & 37 & 30 & - \\
\hline & & 14 & 28 & 38 & 52 & 43 & - \\
\hline & & 28 & 34 & 47 & 63 & 52 & 116 \\
\hline \multirow{9}{*}{ 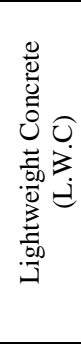 } & \multirow{3}{*}{$\begin{array}{c}\text { Compressive } \\
\text { Strength* } \\
\left(\mathrm{kg} / \mathrm{cm}^{2}\right)\end{array}$} & 7 & 146 & - & 206 & - & - \\
\hline & & 14 & 183 & - & 237 & - & - \\
\hline & & 28 & 219 & - & 296 & - & 349 \\
\hline & \multirow{3}{*}{$\begin{array}{l}\text { Indirect } \\
\text { Tensile } \\
\text { Strength* } \\
\left(\mathrm{kg} / \mathrm{cm}^{2}\right)\end{array}$} & 7 & 12 & - & 21 & - & - \\
\hline & & 14 & 15 & - & 25 & - & - \\
\hline & & 28 & 18 & - & 31 & - & 62 \\
\hline & \multirow{3}{*}{$\begin{array}{l}\text { Flexural } \\
\text { Strength* } \\
\left(\mathrm{kg} / \mathrm{cm}^{2}\right)\end{array}$} & 7 & 18 & - & 33 & - & - \\
\hline & & 14 & 24 & - & 46 & - & - \\
\hline & & 28 & 29 & - & 54 & - & 104 \\
\hline
\end{tabular}

*as an Average of Three Repeats.

It's seem from Figure (3) that, by increasing steel fibers percentage, the compressive strength increased by $21 \%$, $47 \%$ and $30 \%$ (after seven days), 28\%, 51\% and 39\% (after fourteen days), $25 \%, 44 \%$ and $36 \%$ (after twenty eight days) for $0.5 \%, 1 \%$ and $1.5 \%$, respectively, in comparison to control mixture. The increasing in compressive strength due to the presence of steel fibers which lead to arrest crack width and enhance the energy absorption. At $1.5 \%$ of steel fibers mixture, the compressive strength decreased by $11 \%, 8 \%$ and $6 \%$ after seven, fourteen and twenty eight days, respectively in comparison to $1 \%$ of steel fibers mixture. The decreasing of these values due to balling of steel fibers in concrete mixture which lead to generate weak points in different regions.

It's appear from Figure (4) that, indirect tensile strength increased by $23 \%, 85 \%$ and $31 \%$ (after seven days), $19 \%, 81 \%$ and $44 \%$ (after fourteen days), 26\%, 89\% and $53 \%$ (after twenty eight days) for $(0.5 \%, 1 \%$ and $1.5 \%)$ steel fibers mixtures, respectively, in comparison to control mixture. The increasing due to steel fibers ability to enhance mortar strength by forming a metal fibrous mesh coated with mortar to resist tensile force. At $1.5 \%$ of steel fibers mixture, the indirect tensile strength decreased by $29 \%, 21 \%$ and $19 \%$ after seven, fourteen and twenty eight days, respectively in comparison to $1 \%$ of steel fibers mixture. The excessive quantities of steel fibers lead to form gaps in concrete mortar and finally decreased indirect tensile strength.

It's noted from Figure (5) that, flexural strength for $(0.5 \%, 1 \%$ and $1.5 \%)$ steel fibers mixtures increased by $(23 \%$, $68 \%$ and $36 \%),(36 \%, 86 \%$ and $54 \%),(38 \%, 85 \%$ and $53 \%)$ after seven, fourteen and twenty eight days, respectively in comparison to control mixture. The presence of steel fibers in mixture enhanced the capability of prism to absorb more energy and overcome the generated force due to bending moment. Steel fibers stitched the tested prisms and optimized the performance during test. Flexural strength of $1.5 \%$ steel fibers mixture decreased by 19\%, $17 \%$ and $17 \%$ after seven, fourteen and twenty eight days, respectively in comparison to $1 \%$ steel fibers mixture. The reduction due to large amount of steel fibers which lead to decrease mortar strength.

Steel fibers improved the mechanical properties of concrete but the influential values were indirect tensile and flexural strengths. In the case of indirect tensile strength, steel fibers worked to create a steel mesh to resist tensile forces, especially that the distribution of steel fibers was random and be in all directions. The flexural strength recorded high value because it's increased young's modulus and stiffness of concrete. The obtained results gave valuable performance of the fibrous concrete, including the ability to emphasize the use of fiber in multiple applications. It's seem from Table (8) and Figures (3) to (5) that, 1\% of steel fibers (volume fraction) was the optimum value for high performance traditional concrete, hence, this obtained percentage was fixed to produce lightweight concrete and compare it's mechanical properties with obtained mechanical properties of traditional concrete.

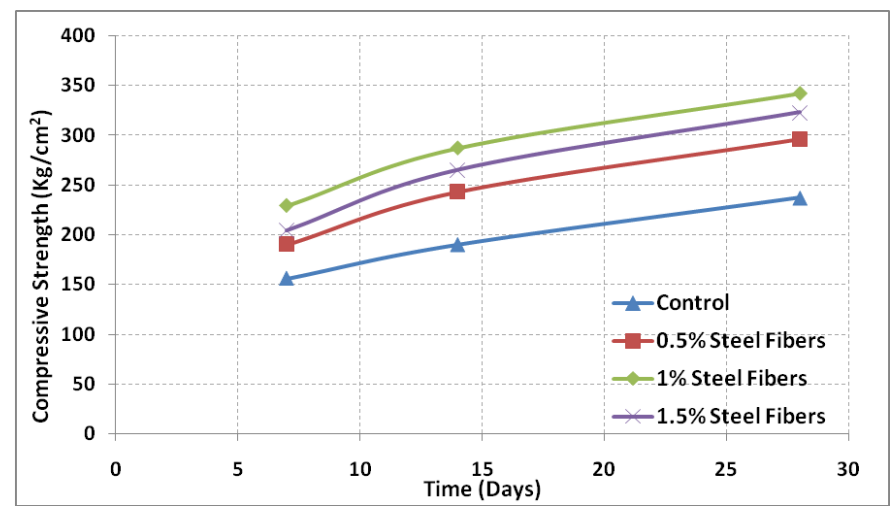

Figure (3): Relationship between Compressive Strength and Steel Fibers Ratios at different Ages

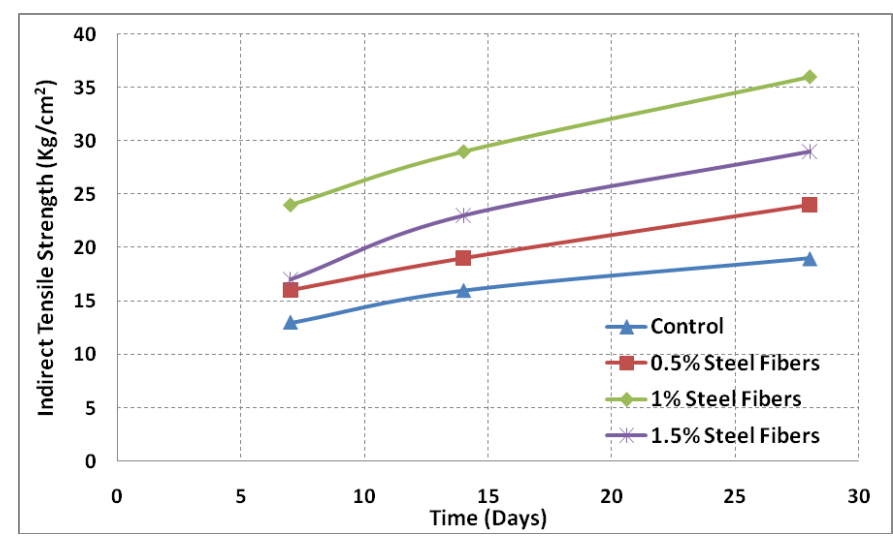

Figure (4): Relationship between Indirect Tensile Strength and Steel Fibers Ratios at different Ages

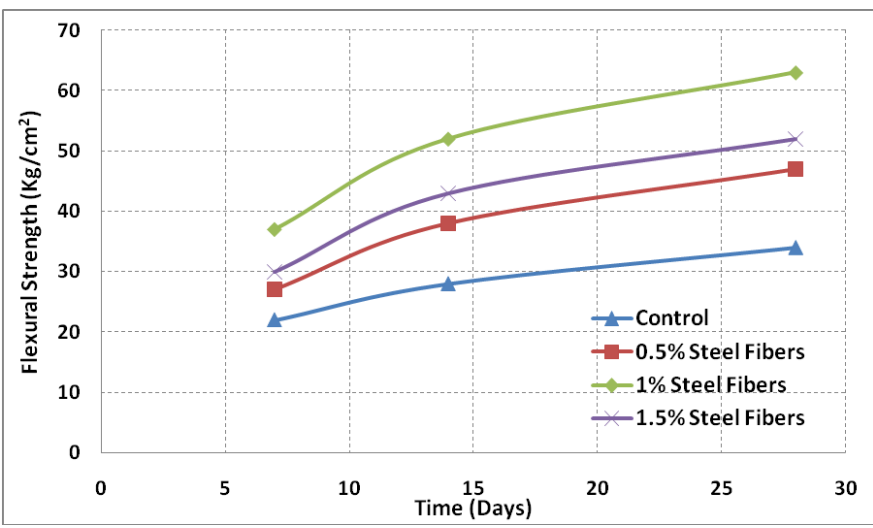

Figure (5): Relationship between Flexural Strength and Steel Fibers Ratios at different Ages

It is clear from Table (9) that, the density of traditional concrete is higher than lightweight concrete by almost $28 \%$ (as an average) based on the existing percentage of steel fibers in concrete mixture. Lightweight mixture 
classified as a lightweight concrete because obtained density value in acceptable limits according to ASTM C330 and ACI:213R-03[9][12].

Table (9): Dry Density for different Tested Concrete

\begin{tabular}{|c|c|c|c|}
\hline Concrete Type & $\begin{array}{c}\% \text { of Steel } \\
\text { Fibers }\end{array}$ & $\begin{array}{c}\text { Density } \\
\left(\mathrm{t} / \mathrm{m}^{3}\right)\end{array}$ & $\begin{array}{c}\text { Specification } \\
\text { Limit* }\end{array}$ \\
\hline $\begin{array}{c}\text { Traditional } \\
\text { Concrete } \\
\text { (T.C) }\end{array}$ & Control & 2.25 & - \\
\cline { 2 - 4 } & $1 \%$ & 2.46 & - \\
\hline $\begin{array}{c}\text { Lightweight } \\
\text { Concrete } \\
\text { (L.W.C) }\end{array}$ & Control & 1.77 & \multirow{2}{*}{1.12 to $1.92 \mathrm{t} / \mathrm{m}^{3}$} \\
\cline { 2 - 4 } & $1 \%$ & 1.89 & \\
\hline
\end{tabular}

*ASTM C330, ACI:213R-03[9][12] .

It's noted from Figure (6) that, the compressive strength of fibrous L.W.C increased by $41 \%$, $30 \%$ and $35 \%$ after seven, fourteen and twenty eight days, respectively in comparison to L.W.C control mixture. The increasing in compressive strength proved that, steel fibers enhanced the strength of L.W.C mixture. For control mixtures, the compressive strength of T.C mixture more than L.W.C mixture by $7 \%, 4 \%$ and $8 \%$ after seven, fourteen and twenty eight days, respectively. Also, Fibrous T.C mixture recorded increasing in compressive strength by $11 \%, 21 \%$ and $16 \%$ in comparison to fibrous L.W.C mixture after seven, fourteen and twenty eight days, respectively. These variations due to low strength of replaced aggregate which lead to fail cubes due to crushing in coarse aggregate.

From Figure (7), the indirect tensile strength of T.C control mixture increased by $8 \%, 7 \%$ and $6 \%$ after seven, fourteen and twenty eight days, respectively in comparison to L.W.C control mixture. The indirect tensile strength of fibrous L.W.C mixture increased by $75 \%, 67 \%$ and $72 \%$ after seven, fourteen and twenty eight days, respectively in comparison to L.W.C control mixture. Fibrous T.C mixture recorded increasing after seven, fourteen and twenty eight days in comparison to fibrous L.W.C mixture by $14 \%, 16 \%$ and $16 \%$, respectively. The reduction in indirect tensile strength due to low strength of aggregate which lead to decrease the bond between aggregate and mortar.

It's revealed from Figure (8) that, the flexural strength of the T.C control mixture more than L.W.C control mixture by $22 \%, 17 \%$ and $17 \%$ after seven, fourteen and twenty eight days, respectively. Flexural strength of fibrous T.C mixture increased by $12 \%, 13 \%$ and 17 after seven, fourteen and twenty eight days, respectively in comparison to fibrous L.W.C mixture. Steel fibers increased flexural strength of fibrous L.W.C mixture by $83 \%, 92 \%$ and $86 \%$ after seven, fourteen and twenty eight days, respectively in comparison to L.W.C control mixture.

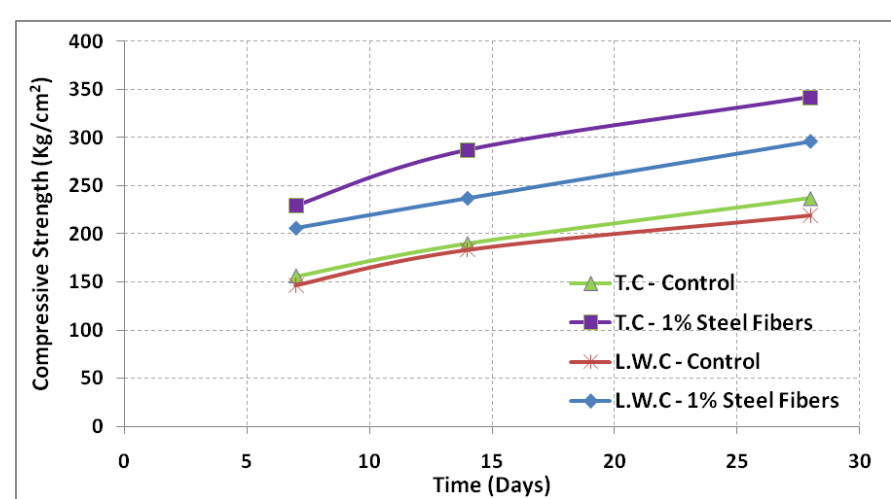

Figure (6): Relationship between Compressive Strength and Steel Fibers Ratios for T.C and L.W.C Mixtures at different Ages

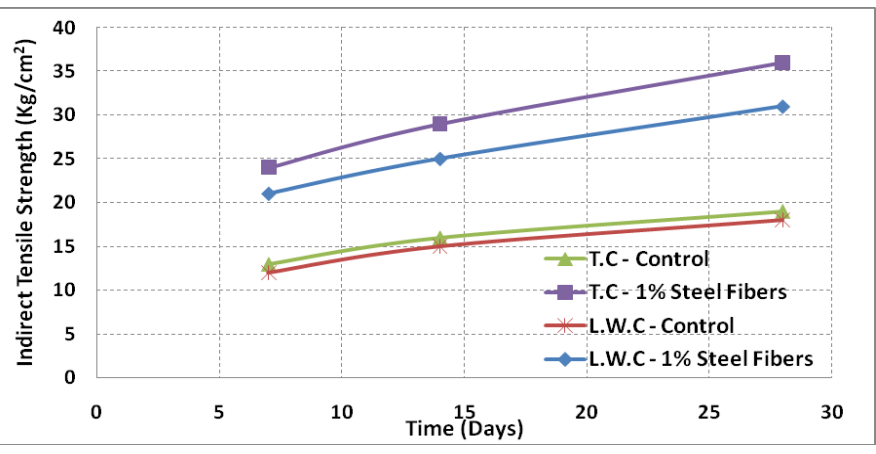

Figure (7): Relationship between Indirect Tensile Strength and Steel Fibers Ratios for T.C and L.W.C Mixtures at different Ages

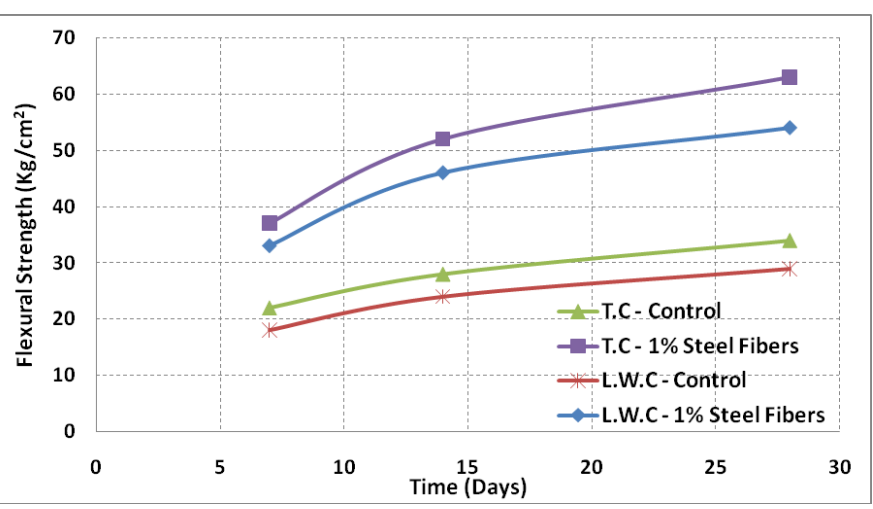

Figure (8): Relationship between Flexural Strength and Steel Fibers Ratios for T.C and L.W.C Mixtures at different Ages

Figure (9) shows that, double action of fibers (1\% steel fibers and external GFRP sheet) enhanced the compressive strength by $71 \%$ and $19 \%$ for control and fibrous T.C mixtures, respectively and by $59 \%$ and $18 \%$ for control and fibrous L.W.C mixtures, respectively. Double action of fibers achieved significant more strength for T.C mixture than L.W.C mixture by $16 \%$. Cube failed by deboning in external GFRP sheet then vertical crack was observed and finally failed by splitting crushing failure mechanism. The obtained results revealed that, the usage of double action of fibers improved the behavior of concrete, whether T.C or L.W.C.

Figure (10) shows that, double action of fibers enhanced the indirect tensile strength by $253 \%$ and $86 \%$ for control and fibrous T.C mixtures, respectively and by $244 \%$ and $200 \%$ for control and fibrous L.W.C mixtures, respectively. Double action of fibers achieved significant more strength for T.C mixture than L.W.C mixture by $8 \%$. Cylinder was subjected to indirect tensile force which lead to vertical 
crack then splitting failure was observed in concrete. The obtained results confirmed that, the usage of double action of fibers improved the performance of concrete, whether T.C or L.W.C.

Figure (11) shows that, double action of fibers enhanced the flexural strength by $241 \%$ and $84 \%$ for control and fibrous T.C mixtures, respectively and by $259 \%$ and $93 \%$ for control and fibrous L.W.C mixtures, respectively. Double action of fibers achieved significant more strength for T.C mixture than L.W.C mixture by $12 \%$. Cracks appeared at the bottom of middle third of prisms due to the effect of double concentrated loads and failed due to propagation of cracks under the effect of pure bending moment (flexure failure). The obtained results confirmed that, the usage of double action of fibers improved the performance of concrete, whether T.C or L.W.C.

Double action of fibers, generally, improved concrete strength and gave a distinct performance for concrete. This improvement appeared very clear in the case of indirect tensile strength and flexural strength. Performance exceeded expectations especially for L.W.C. of the obtained results, L.W.C can be use in structural applications, especially if it was mixed with $1 \%$ steel fibers and strengthened with external GFRP sheet (double action of fibers).

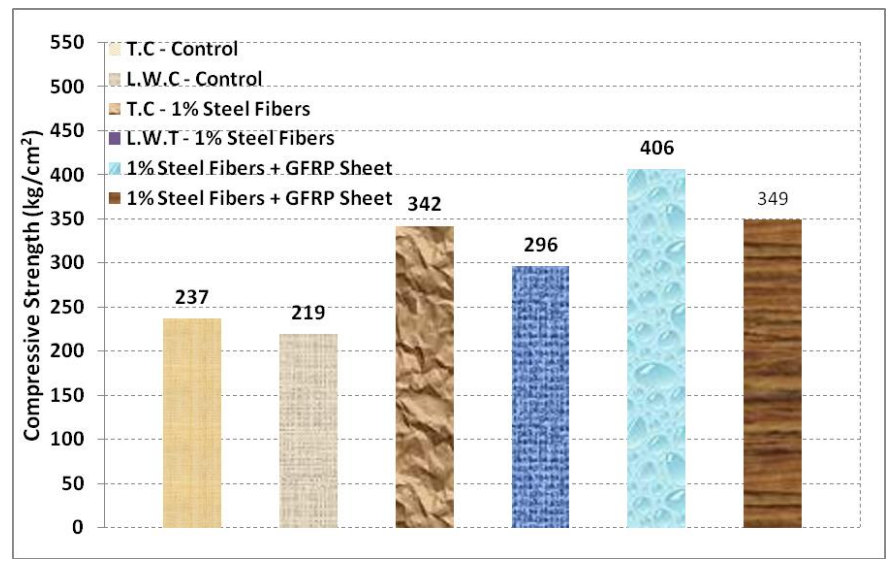

Figure (9): Compressive Strength for T.C and L.W.C Mixtures after Twenty Eight Days

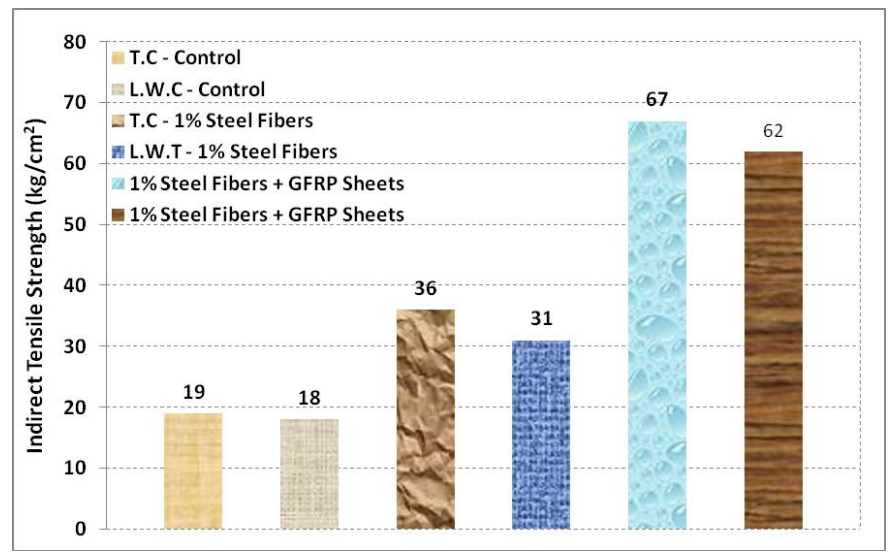

Figure (10): Indirect Tensile Strength for T.C and L.W.C Mixtures after Twenty Eight Days

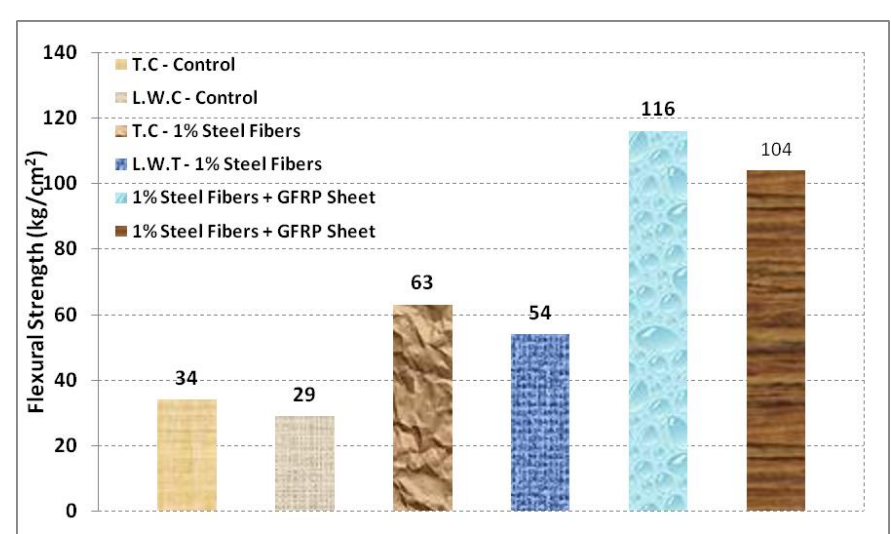

Figure (11): Flexural Strength for T.C and L.W.C Mixtures after Twenty Eight Days

\section{CONCLUSIONS}

The results show a great achievement for using steel fibers as an enhancer material. It's worth to be mention that, double action of fibers enhanced concrete performance significantly. Use the waste is a major challenge in the concrete industry but the results showed the optimum use of waste lightweight sand bricks. The results can be summarized by the following points:

1. By increasing steel fibers percentage, the compressive strength increased by $21 \%$ to $51 \%$ (based on testing time of concrete) in comparison to control mixture. At $1.5 \%$ of steel fibers mixture, the compressive strength decreased by $6 \%$ to $11 \%$ (based on testing time of concrete) in comparison to $1 \%$ of steel fibers mixture. The indirect tensile strength increased for fibrous mixtures by $19 \%$ to $89 \%$ (based on testing time of concrete) in comparison to control mixture. Also, the indirect tensile strength of $1.5 \%$ of steel fibers mixture decreased by $19 \%$ to $26 \%$ (based on testing time of concrete) in comparison to $1 \%$ of steel fibers mixture. Flexural strength increased for fibrous mixtures by $23 \%$ to $86 \%$ (based on testing time of concrete) in comparison to control mixture. By the way, flexural strength of $1.5 \%$ steel fibers mixture decreased by $17 \%$ to $19 \%$ (based on testing time of concrete) in comparison to $1 \%$ steel fibers mixture.

2. Generally, using steel fibers in concrete transfers failure mode from brittle to semi-ductile failure due to arresting of cracks surfaces in concrete elements and GFRP sheets together with steel fibers make a good integration that absorbs energy and resist impact load perfectly and transfer the brittle failure of traditional concrete to semi-ductile failure and at $1 \%$ steel fibers the mechanical properties of T.C mixture enhanced with idealized behavior.

3. Using the waste of lightweight sand bricks as an aggregate preserved the environmental and gave impressive results in concrete behavior and coating the lightweight sand bricks aggregate with resin (unsaturated polyester and peroxide) and dry cement mortar optimized the performance of aggregate in concrete. It's worth to be mention that, the coating materials doesn't affect the cost in so far as reducing absorption and lime insulation in the aggregate to prevent its long-term interaction with concrete which lead to reduce its strength. 
4. The density of traditional concrete is higher than lightweight concrete by almost $28 \%$ and this value based on the existing percentage of steel fibers in concrete mixture.

5. The compressive strength of fibrous L.W.C increased by $30 \%$ to $41 \%$ (based on testing time of concrete) in comparison to L.W.C control mixture. For control mixtures, the compressive strength of T.C mixture more than L.W.C mixture by $4 \%$ to $8 \%$ (based on testing time of concrete). Also, Fibrous T.C mixture recorded increasing in compressive strength by $11 \%$ to $21 \%$ (based on testing time of concrete) in comparison to fibrous L.W.C mixture.

6. The indirect tensile strength of T.C control mixture increased by $6 \%$ to $8 \%$ (based on testing time of concrete) in comparison to L.W.C control mixture. However, the indirect tensile strength of fibrous L.W.C mixture increased by $67 \%$ to $75 \%$ (based on testing time of concrete) in comparison to L.W.C control mixture. Based on testing time of fibrous T.C mixture, the indirect tensile strength increased in comparison to fibrous L.W.C mixture by $14 \%$ to $16 \%$.

7. The flexural strength of the T.C control mixture more than L.W.C control mixture by $17 \%$ to $22 \%$ (based on testing time of concrete). Flexural strength of fibrous T.C mixture increased by $12 \%$ to $17 \%$ (based on testing time of concrete) in comparison to fibrous L.W.C mixture. Steel fibers increased flexural strength of fibrous L.W.C mixture by $83 \%$ to $92 \%$ (based on testing time of concrete) in comparison to L.W.C control mixture.

8. The effect of double action of fibers (1\% steel fibers and external GFRP sheet) enhanced the compressive strength by $71 \%$ and $19 \%$ for control and fibrous T.C mixtures, respectively and by $59 \%$ and $18 \%$ for control and fibrous L.W.C mixtures, respectively. Also, the indirect tensile strength increased by $253 \%$ and $86 \%$ for control and fibrous T.C mixtures, respectively and by $244 \%$ and $200 \%$ for control and fibrous L.W.C mixtures, respectively. On the other hand, the flexural strength increased by $241 \%$ and $84 \%$ for control and fibrous T.C mixtures, respectively and by $259 \%$ and $93 \%$ for control and fibrous L.W.C mixtures, respectively.

9. Double action of fibers (1\% steel fibers and external GFRP sheet) achieved significant more strength for T.C mixtures than L.W.C mixtures by $16 \%, 8 \%$ and $12 \%$ for compressive strength, indirect tensile strength and flexural strength, respectively.

\section{REFERENCES}

[1] Mahmoud Hassan pour, Payam Shafigh, Hilmi Bin Mahmud (2012), "Lightweight aggregate concrete fiber reinforcement - A review", Construction and Building Materials, Volume 37, December 2012, Pages 452-461.

[2] R.Yua D.V.van, OnnaaP.Spiesz, Q.L.Yu, H.J.H.Brouwers (2016), "Development of Ultra-Lightweight Fibre Reinforced Concrete applying expanded waste glass", Journal of Cleaner Production, Volume 112, Part 1, 20 January 2016, Pages 690-701.

https://doi.org/10.1016/j.jclepro.2015.07.082Get rights and content

[3] N. Sivalinga Rao, Y.Radha Ratna Kumari, V. Bhaskar Desai, B.L.P. Swami (2013), "Fibre Reinforced Light Weight Aggregate (Natural Pumice Stone) Concrete", International Journal of Scientific \& Engineering Research Volume 4, Issue 5, May-2013.

[4] Aghaee, K, Yazdi, MA and Tsavdaridis, KD (2014), "Mechanical properties of structural lightweight concrete reinforced with waste steel wires", Magazine of Concrete Research, (1). 1 - 9. https://doi.org/10.1680/macr.14.00232

[5] ES:1109/2002, Egyptian Standards for Natural Aggregate.

[6] ES:4756-1/2009, Egyptian Standards for Cement.

[7] BS:5328, British Standard for Concrete Mix Design, Concrete, Part 2.

[8] BS:12390, British Standard for Testing Hardened Concrete.

[9] ASTM C330, Standard Specification for Lightweight Aggregate For Structural Concrete.

[10] Gouda Ghaniem, Nagi Fouad, Tarek Ali, Sameh Yehia (2009), "Behavior of Short RC Columns Reinforced with FRP Bars", News of the Kazan State University of Architecture and Engineering Journal, ISSN:2073-154X, 2(12), 2009.

[11] AISI 1010, American Iron and Steel Institute.

[12] ACI:213R-03, Guide for Structural Lightweight-Aggregate Concrete.

[13] ECP:208-2005, Egyptian Code of Practice for Using Fiber Reinforced Polymers in Construction.

[14] ACI:440, Guide for the Design and Construction of Externally Bonded FRP Systems for Strengthening Concrete Structures. 